\title{
Adaptation Pattern of Lerep Village as Thematic Climate Program in Dealing with Global Warming
}

\author{
Sriyanto $^{1}$, Edi Kurniawan ${ }^{2}$ Muhammad Afwan Maulana ${ }^{3}$ \\ \{sriyantogeo@mail.unnes.ac.id ${ }^{1}$, edikurniawan@mail.unnes.ac.id ${ }^{2}$, muh.afwanmaulana24@gmail.com ${ }^{3}$ \}
}

Universitas Negeri Semarang, Indonesia ${ }^{1}$

\begin{abstract}
Indonesia is one of the countries participating in reducing greenhouse Gas emissions that have been agreed in the Kyoto protocol by creating a climate village Program which is then abbreviated as ProKlim. ProKlim is an effort to adapt and mitigate climate change based on community empowerment. One of the places that are currently running the climate village Program in Semarang District is Lerep Village, district of West Ungaran, Semarang regency. There are two indicators in the implementation of the Climate Farm Program (Proklim), which is an effort to adapt and mitigate climate change. The adaptation effort made by the community of Lerep Village is the harvesting of rainwater by creating a tub or tandon water shelter. Efforts to maintain groundwater availability is also done by making Biopori and a well-recent well. The water source is maintained while retaining the vegetation surrounding the springs. The second indicator of climate change mitigation is done by waste management with the presence of waste banks in the community. Garbagehousehold waste is used as a compost material, both liquid and solid. Some places where the vegetation cover is less, planted with annual hard crops. These activities refer to the form of the adaptation pattern of the community of Lerep village as the village climate Program.
\end{abstract}

Keywords: Adaptation Pattern, Proklim, Global Warming

\section{Introduction}

Climate change is currently a serious threat to life on earth . This phenomenon one of the causes is the increase of temperature globally triggered with the increase the content greenhouse gas in the atmosphere The impact of that can be perceived is the phenomenon increasing the level water the sea and temperature the surface that is being higher than with the 10 years ago. For mountainous regions the impacts of global warming were that more and more at least the water found.

The Indonesian Government through the ministry of the environment and forestry introduced their climate (proklim) stipulated in the environment minister and forestry no. 19 2012. The environmental ministry and forestry have targeted about 2,000 location that is spread across indonesia would be used as their climate on in 2019. It is a step in strengthening proklim real action at the local level that will contribute to efforts to mitigate to reduce greenhouse gas emissions. This is also an attempt adaptation to increase the capacity of all institutions in the face of the impact of climate change.

Ghina [1] said that indonesia was one of the countries who participates in the reduction of greenhouse gases that have been agreed in the kyoto protocol by making a climate that village program then abbreviated to proklim. Proklim is an attempt to climate change adaptation and mitigation community empowerment. Their reality the climate adaptation and mitigation 
comprise activities carried out by the community in facing or prevent the impact of climate change. Village program the climate can be developed and implemented in the area and implemented in the area at least at the same level the village level [2].

Climate (proklim village program) has launched as the national movement of climate change control based on community groups by environment minister and forestry on $1^{\text {st }}$ December 2016. Since proklim that have been conducted by 2012, transformed of delivering a form of appreciation to the lowest in the rank of administrative territorial / hamlet and the highest of the rank of a village, to encourage and facilitate the other financial markets grow their enrichment program through innovation climate adaptation and mitigation the real climate change be implemented in the collaboration of the government.

One of the running their village program climate in the district is located in Semarang is Lerep, village in west Ungaran District. The Lerep Village implement their climate with local knowledge they. Local knowledge is one of a community participation in to maintain and preserve the environment [3].This article explains how to pattern adaptation villagers lerep in dealing with global warming and its impact as village thematic village program climate in terms of indicators to climate change adaptation and mitigation.

\section{Research Method}

Data collecting was implemented through a number of techniques, observation, the objective of the interview and documentation and the distribution of the, other of any economic indicators. In order to support the data, document retrieval is conducted as a evidence against the data. There are two variables become the focus of their intention is nothing but been disclosed in the research climate change adaptation and mitigate the climate change. In order to make clear data was undertaken by description with a model double of of the source of data.

\section{Result and Discussion}

The village Lerep is one of tourist village that is in Semarang Regency, precisely in either West Ungaran District. As of the villages are located in mountainous regions has made Lerep have a role that has a significant to maintain environmental sustainability. The village Lerep, the west Ungaran District situated in the part upstream from a river flow areas truculent. The life of the people come from a large proportion of the livelihoods as farmers by making use of that land in around the house as well as in a garden.

Village as the lerep proklim cause the village lifestyle changed. To support the they to be proklim particularly in supporting greenhouse gas emission reduction with local knowledge and. Adaptation the community in facing the global warming phenomena village community can lerep outlined in two main activities, the climate change adaptation and mitigation.

\subsection{Climate Change Adaptation}

On the variables of are some of the activities be an indicator of climate change adaptation namely control drought, flood and landslide.

\section{a) Harvesting Rainwater and Peresapan Water}


As village is located in the mountains should will have no trouble with the presence of water, especially water for their daily. But, with the phenomenon global warming have a fairly significant impact for life. New season an abnormal the dry season more long requires people will use short the rainy season well. Techniques used by the community Lerep is to harvest rainwater which is to build full tank their shelter in some point. Not all in the village Lerep is harvesting water because the village beneath which directly water from the water Ungaran mountain, but in a point near the field there are places large for rainwater storage to anticipate the lack of water as the drought. Figure 1 show by that provided society by making the shelter for harvest water. Village Lerep in some points made available to absorb surface water will help puddle caused erosion. But available because the drafting old so the area many covered by vegetation.

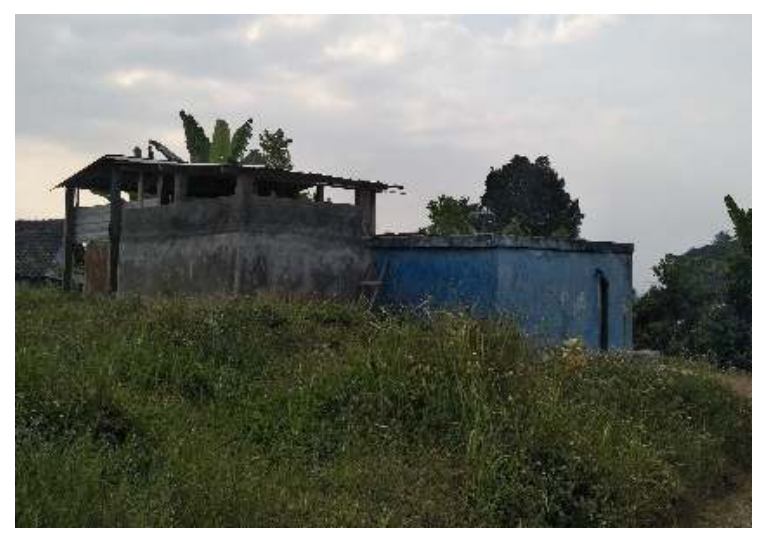

Fig.1 The shelter harvesting rain

\section{b) Management and Protection Springs}

Village Lerep located in a mountain ridge Ungaran north to upstream from time pugnacious. There are some springs appeared in village lerep made the area does not will lacks when dry season. But it is the springs smaller every second debit. Based on the data from the village administration Lerep have many sources springs, dimpil: springs the Lutung, springs Wudel, springs Bulus, springs Songo, springs Wonosari, and springs Tegal Gawok. To keep the the springs, people of village greening with the government around the eyes from the water. Tree planting hard in the mango tree, atrvocado, durian and also with alternative Banyan tree. The other activities to guard and protect the water is to hold Iriban tradition. This tradition held twice a year but to clean water channel. Figure 2 image shows Iriban tradition implemented in the village Lerep.

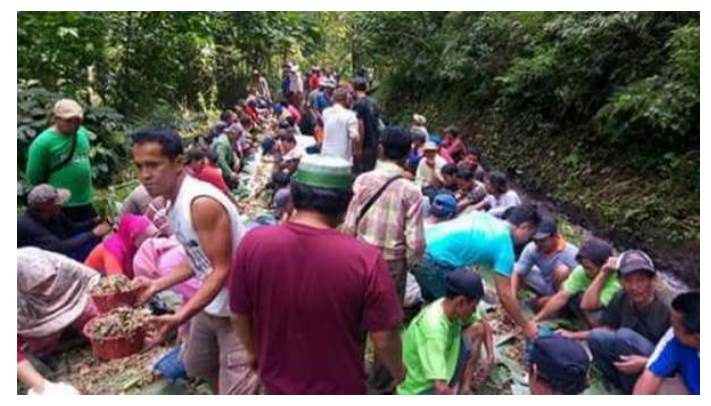


Figure 2. The Iriban tradition in Lerep Village

\section{c) Providing the Flood Control}

People uses a pipe to flow water from the spring to the houses and trench to drain water from a spring /. upstream to downstream. A trench created by the Lerep's to flow water from the spring to fields near village.

Food security became one of indicators adaptation the community in in overcoming global warming according to government regulation no. 19/2012 [2]. A pattern adaptation the community Lerep in food security with diversify food crops. While most of the field before the earn their livelihood as farmers' rice and sound also cultivate food crops apart from rice in the form of cassava and corn. In addition, residents also plant cloves and coffee. Planting patterns done by following the season for rice fields, while for gardens performed with (figure 3) use intercropping as technique. As in other mountainous regions, the agricultural techniques the completion of land use the model terasering to minimize and land to prevent landslides.

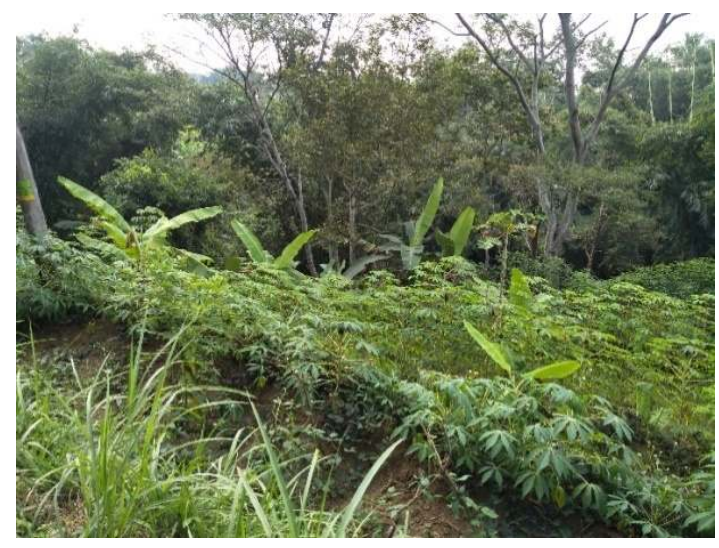

Figure 3. Intercropping system fermented cassava tree, banana and perennials (sengon) in Lerep

\subsection{Mitigate the Climate Change}

Activities mitigate the climate change in climate village program there are two namely garbage management and veils vegetation as well as the improvement of solid waste.

\section{a) Garbage and Solid Waste Management}

The goal is to reduce and prevent the use of hazardous waste that can produce goods for the environment. The garbage in the village Lerep have started to manage well, namely with existence of the trash at each corner of the village. Of the people place bits and pieces made of a sack in many strategic points villages and make large shelter at some point in the future will directly transported by trucks and later discarded to the dump (fig 4). 


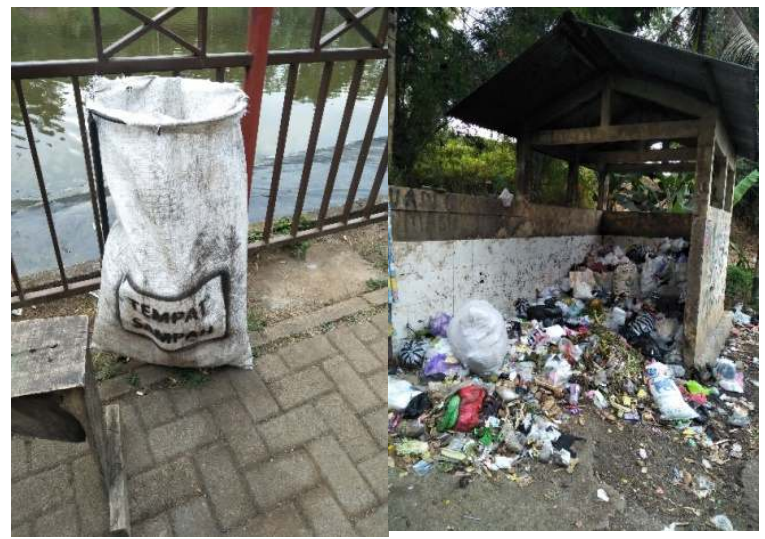

Fig. 4 The trash that existed in the Lerep

\section{b) A Covering of Vegetation}

Vegetations is the form of upgrading activities covering. The more vegetation will cover could reduce the micro temperature. Besides it can also prevent flood disaster. Landslide with community members from outside Lerep as the students and CSO do reboization in critical areas in the region Critical areas are and high levels of the slope. Landslides happened in Sukolilo (Lerep) in 2013 (fig 5). Was caused by the lack of a land of perennials besides high rainfall although no casualties but loss of wealth occur.

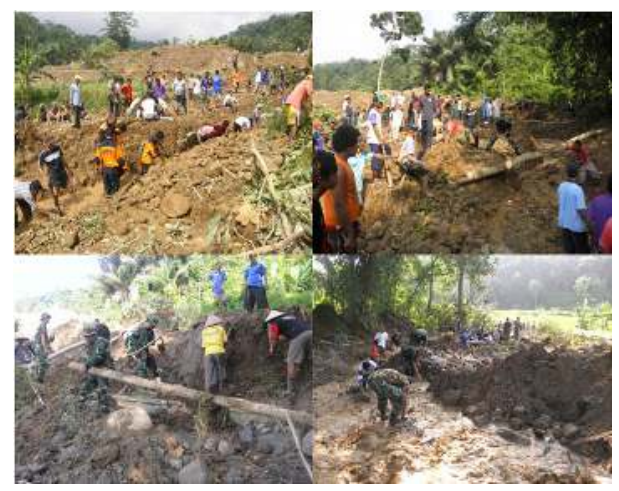

Fig. 5 Landslides in Lerep Village in 2013

Global warming has become the world problems, but from the local level needed to prevent or reduce. Indonesia Government as one of part of the community in the world to make climate village program (proklim) stated in the minister for environment and forestry no. 19/2012 [2]. Villages Lerep to implement the program to outline programs in the community which is the local knowledge. Eventually, global warming we can slow down the process or even prevented starts from. environment around us. 


\section{Conclusion}

The Lerep Village implement their climate with local knowledge they. Local knowledge is one of a community's participation in to maintain and preserve the environment. This article explains how to pattern adaptation villagers in Lerep in dealing with global warming and its impact as village thematic village program climate in terms of indicators to climate change adaptation and mitigation. There are two indicators in the implementation of the Climate Farm Program (Proklim), which is an effort to adapt and mitigate climate change. The adaptation effort made by the community of Lerep Village is the harvesting of rainwater by creating a tub or tandon water shelter. Efforts to maintain groundwater availability is also done by making Biopori and a well-recent well. The water source is maintained while retaining the vegetation surrounding the springs. The second indicator of climate change mitigation is done by waste management with the presence of waste banks in the community. Garbage-household waste is used as a compost material, both liquid and solid. Some places where the vegetation cover is less, planted with annual hard crops. These activities refer to the form of the adaptation pattern of the community of Lerep village as the village climate Program.

\section{References}

[1] N. Y. Ghina, "KAMPUNG IKLIM: PENGELOLAAN LINGKUNGAN BERBASIS PEMBERDAYAAN MASYARAKAT.” Universitas Sebelas Maret, 2017.

[2] P. Indonesia, Peraturan Menteri Negara Lingkungan Hidup Republik Indonesianomor 19 Tahun 2012 Tentang Program Kampung Iklim. Jakarta: Kementerian Lingkungan Hidup Indonesia, 2012.

[3] M. Sriyanto, E. Kurniawan, and H. S. Aji, "Local wisdom of Kandri Village as a form of Environmental Conservation," in International Conference on Rural Studies in Asia (ICoRSIA 2018), 2019. 